\title{
A functional Notch-survivin gene signature in basal breast cancer
}

\author{
Connie W Lee1, Karl Simin¹, Qin Liu², Janet Plescia'1, Minakshi Guha1', Ashraf Khan³, Chung- \\ Cheng Hsieh ${ }^{1}$ and Dario C Altieri ${ }^{1}$
}

\author{
1Department of Cancer Biology and the Cancer Center, University of Massachusetts Medical School, 364 Plantation Street, Worcester, MA 01605, \\ USA \\ ${ }^{2}$ Department of Medicine, Preventive and Behavioral Medicine, University of Massachusetts Medical School, 364 Plantation Street, Worcester, MA \\ 01605, USA \\ ${ }^{3}$ Department of Pathology, University of Massachusetts Medical School, 364 Plantation Street, Worcester, MA 01605, USA \\ Corresponding author: Dario C Altieri, dario.altieri@umassmed.edu
}

Received: 21 Jul 2008 Revisions requested: 27 Aug 2008 Revisions received: 12 Nov 2008 Accepted: 24 Nov 2008 Published: 24 Nov 2008

Breast Cancer Research 2008, 10:R97 (doi:10.1186/bcr2200)

This article is online at: http://breast-cancer-research.com/content/10/6/R97

(C) 2008 Lee et al.; licensee BioMed Central Ltd.

This is an open access article distributed under the terms of the Creative Commons Attribution License (http://creativecommons.org/licenses/by/2.0), which permits unrestricted use, distribution, and reproduction in any medium, provided the original work is properly cited.

\begin{abstract}
Introduction Basal-type, or triple-negative, breast cancer (lacking estrogen receptor, progesterone receptor, and human epidermal growth factor receptor-2 expression) is a high-risk disease for which no molecular therapies are currently available. We studied genetic signatures of basal breast cancer potentially suitable for therapeutic intervention.

Methods We analyzed protein expression of the Notch-1 intracellular domain and survivin by immunohistochemistry in a series of basal breast cancer patients. A hierarchical clustering and overall survival analysis was carried out on a microarray mRNA database of 232 breast cancer patients. Fifteen published mRNA datasets containing estrogen receptornegative or estrogen receptor-positive samples were subjected to meta-analysis for co-segregated gene expression. Experiments of plasmid transfection and gene silencing were carried out in estrogen receptor-negative MDA-MB-231 breast cancer cells.
\end{abstract}

Results The developmental signaling regulator Notch-1 was highly expressed in breast cancer, compared with normal tissue, and was segregated with basal disease. Higher Notch-1 levels correlated with progressively abbreviated overall survival, and with increased expression of survivin, a tumor-associated cell death and mitotic regulator implicated in stem cell viability. Analysis of Pearson's correlation coefficient indicated that Notch-1 and survivin co-segregated in basal breast cancer. Notch-1 stimulation in MDA-MB-231 cells increased survivin expression, whereas silencing Notch reduced survivin levels.

Conclusions A Notch-1-survivin functional gene signature is a hallmark of basal breast cancer, and may contribute to disease pathogenesis. Antagonists of Notch and survivin currently in the clinic may be tested as novel molecular therapy for these recurrence-prone patients.

\section{Introduction}

The introduction of molecular gene signatures in breast cancer provides important prognostic and predictive information [13], and holds promise for individualized molecular therapy of these patients [4]. Certain subtypes of breast cancer, however, continue to pose therapeutic challenges [4]. For example, basal breast cancer is a myoepithelial disease variant characterized by high histologic grade [5], by the absence of HER-2 (ErB2) and receptors for estrogen and progesterone [6], by the expression of basal cytokeratins (that is, keratin 5) and proliferation-associated genes $[7,8]$, as well as by defects in genomic gatekeepers, p53, or BRCA1 [9]. While immunohistochemical diagnosis of basal breast cancer is straightforward [6], these patients have limited therapeutic options: the response to mainstay chemotherapy is not uniform and is affected by the type of drugs used [10]; estrogen or HER-2 targeting is not indicated; and attempts to disable ancillary signaling pathways, for instance coordinated by the epidermal growth factor receptor, have so far shown little promise [11]. This adds to a high rate of relapses, which in several series has been linked to shortened overall survival and to death from disease [12]. 
Although the cell of origin of basal breast cancer has not been conclusively identified [5], a link to the progenitor/stem cell compartment of the mammary epithelium has been proposed [13]. In this context, developmental gene expression pathways that control the interplay between cell proliferation, survival, and differentiation are candidates for stem cell-derived mammary tumorigenesis [14]. One such pathway is centered on the Notch family of cell surface receptors [15] - which affects the mammary stem cell niche [16], and has been associated with malignant transformation [17] and aggressive tumor behavior [18]. Notch expression is correlated to human breast cancer formation but the downstream pathways that guide such behavior are still under investigation $[19,20]$.

Among the candidate effector molecules controlling stem cell viability is survivin, a dual regulator of cell division and apoptosis, broadly overexpressed in cancer [21]. Consistent with its onco-fetal pattern of expression, survivin is essential for tissue homeostasis [21] - and conditional knockout studies have suggested a potential critical role of this pathway in maintaining stem cell viability, at least in certain tissue compartments [22].

In the present study, we used a combination of hierarchical clustering and overall survival analysis of a novel microarray dataset, meta-analysis of published gene profiling studies, and cell culture experiments to investigate a potential role of a Notch-1-survivin signaling axis in breast cancer.

\section{Materials and methods Immunohistochemistry}

Nine cases of basal breast cancers with associated clinical and pathological data were obtained from the archives of the Department of Pathology, University of Massachusetts Medical School. Analysis of anonymous discarded tissue with no patient identifiers was approved by and in compliance with Institutional Review Board guidelines.

Tissue sections $(5 \mu \mathrm{m})$ were cut from paraffin blocks, deparaffinized in xylene, rehydrated, and baked overnight at $60^{\circ} \mathrm{C}$. Slides were quenched for endogenous peroxidase with $3 \%$ $\mathrm{H}_{2} \mathrm{O}_{2}$ in methanol for 20 minutes, and were processed for antigen retrieval by pressure cooking in $9 \mathrm{mM}$ sodium citrate, $\mathrm{pH}$ 6.0 , for 20 minutes. Slides were washed in PBS, and incubated overnight at $4^{\circ} \mathrm{C}$ with a rabbit antibody to the Notch-1 intracellular domain (NIC) or control lgG, were rinsed, and were further incubated with a biotinylated anti-rabbit lgG for 10 minutes at $22^{\circ} \mathrm{C}$. After addition of streptavidin-conjugated horseradish peroxidase, the slides were incubated with $3^{\prime}, 3^{\prime}$ diamino-benzidine for 3 to 10 minutes, and were counterstained with hematoxylin, as described previously [23].

\section{Hierarchical clustering analysis of Notch-1 mRNA expression in breast cancer}

The $\log _{2}$ Cy5/Cy3 ratios of 232 cases of human breast cancer and their associated clinical data were downloaded from the University of North Carolina Microarray Database [24,25]. Only genes where the Lowess normalized intensity values in both channels were $>30$ and data existed in $>70 \%$ samples were included for analysis. The gene set was further filtered to include only genes with Pearson's correlation coefficient $>$ 0.58 with Notch-1 $(\mathrm{n}=101)$.

Two-way hierarchical clustering was performed using Cluster v3 [26], and the results were displayed using JavaTreeview [27]. Analysis of overall survival (log-rank test) was carried out using JMP 6.0 [28] (SAS Institute, Cary, NC, USA) on the subset of breast cancer patients in this cohort with available clinical data $(n=125)$. Data were plotted for each quartile of normalized Notch-1 $\log _{2}$ ratios, from highest (first quartile) to lowest (fourth quartile). The breast cancer patients were further divided into basal $(n=35)$ or nonbasal $(n=88)$ subgroups and were analyzed for overall survival (log-rank test) using JMP 6.0 [28].

\section{Meta-analysis of Oncomine microarray data}

We reviewed Oncomine [29,30] for independent human breast cancer microarray datasets comparing estrogen receptor (ER)-negative and ER-positive tumors. Databases from 15 studies were found to contain Notch-1 and survivin relative expression data. The patient characteristics and analyses performed in each study are summarized in Table 1. Descriptive statistics including the mean, standard error, and a two-tailed unpaired $t$ test were calculated for the comparisons between ER-positive and ER-negative samples within each study. Separately for ER-negative and ER-positive samples, a Pearson's correlation coefficient $(r)$ was calculated for each study to measure levels of pair-wise co-expression between Notch-1, survivin, and keratin-5.

The 95\% confidence interval for $r$ was calculated based on Fisher's $Z$ transformation [31]. In one study a Fisher's $Z$ transformation could not be performed for ER-negative samples ( $\mathrm{n}$ =3) [32], and an approximate variance for a Pearson's correlation coefficient was used to derive its 95\% confidence interval. To summarize ER-specific results from the individual studies, Fisher's $Z$ transformation and its variance were used in pooling correlation from different studies. The weighted average of Fisher's $Z$ transformation and its 95\% confidence interval were first estimated based on a fixed-effect model, taking into account the variance associated with each study. The ER-specific pooled estimate of Pearson's correlation coefficient and its $95 \%$ confidence interval were then derived from the estimates based on the Fisher's $Z$ transformation. We applied a random-effect model for meta-analysis [33] to evaluate whether levels of co-expressions between Notch-1, sur- 
Table 1

Published datasets included in the meta-analysis

\begin{tabular}{|c|c|c|c|c|c|c|c|}
\hline Study & $n$ & $\begin{array}{l}\text { Median age } \\
\text { (years) }\end{array}$ & Microarray & Tumor size & $\begin{array}{l}\text { Lymph nodes } \\
\text { (LN) }\end{array}$ & Treatment & Stage/grade \\
\hline $\begin{array}{l}\text { Chin and } \\
\text { colleagues } \\
\text { [55] }\end{array}$ & 118 & $\begin{array}{l}55.3 \\
(S D=14.3)\end{array}$ & Affymetrix & $\begin{array}{l}2.6 \mathrm{~cm} \\
(\mathrm{SD}=1.3)\end{array}$ & $\begin{array}{l}67 \mathrm{LN} \text {-positive, } \\
51 \mathrm{LN} \text {-negative }\end{array}$ & $\begin{array}{l}60 \% \text { tamoxifen, } \\
52 \% \text { adjuvant } \\
\text { chemotherapy, } \\
51 \% \text { radiation }\end{array}$ & $\begin{array}{l}26 \text { stage } 1,70 \\
\text { stage } 2,14 \\
\text { stage } 3,5 \text { stage } \\
4 ; 10 \text { grade } 1, \\
42 \text { grade } 2,61 \\
\text { grade } 3 ; 5 \\
\text { unknown }\end{array}$ \\
\hline $\begin{array}{l}\text { Desmedt and } \\
\text { colleagues } \\
\text { [56] }\end{array}$ & 198 & $47($ all $<61)$ & Affymetrix & $<5 \mathrm{~cm}$ & Node-negative & & $\mathrm{T} 1-\mathrm{T} 2$ \\
\hline $\begin{array}{l}\text { Ginestier and } \\
\text { colleagues } \\
\text { [57] }\end{array}$ & 55 & & Affymetrix & & & $\begin{array}{l}19 \text { amplified for } \\
20 q 13,36 \\
\text { unamplified for } \\
20 q 13\end{array}$ & $\begin{array}{l}\text { Consecutive } \\
\text { cases, unilateral } \\
\text { localized } \\
\text { invasive breast } \\
\text { cancer }\end{array}$ \\
\hline $\begin{array}{l}\text { Hess and } \\
\text { colleagues } \\
{[58]}\end{array}$ & 133 & $\begin{array}{l}\text { Training set, } 52 \\
\text { (range } 29 \text { to } \\
79 \text { ); validation } \\
\text { set, } 50 \\
\text { (range } 28 \text { to } \\
73 \text { ) }\end{array}$ & Affymetrix & & & $\begin{array}{l}\text { Preoperative } \\
\text { weekly paclitaxel } \\
\text { and fluorouracil- } \\
\text { doxorubicin- } \\
\text { cyclophosphami } \\
\text { de } \\
\text { chemotherapy }\end{array}$ & $\begin{array}{l}\text { Stage I, stage II, } \\
\text { stage III }\end{array}$ \\
\hline $\begin{array}{l}\text { Ivshina and } \\
\text { colleagues } \\
\text { [59] }\end{array}$ & $\begin{array}{l}249 \\
\text { (Uppsala } \\
\text { cohort) }\end{array}$ & 62.3 & Affymetrix & $2.9 \mathrm{~cm}$ & $\begin{array}{l}35 \% \text { node- } \\
\text { positive }\end{array}$ & $\begin{array}{l}30.3 \% \\
\text { endocrine } \\
\text { therapy, } 10.7 \% \\
\text { chemotherapy, } \\
1.7 \% \\
\text { combination } \\
\text { therapy, } 58.8 \% \\
\text { no systemic } \\
\text { therapy }\end{array}$ & $\begin{array}{l}68 \text { grade } 1,126 \\
\text { grade } 2,55 \\
\text { grade } 3\end{array}$ \\
\hline $\begin{array}{l}\text { Miller and } \\
\text { colleagues } \\
{[60]}\end{array}$ & 251 & $\begin{array}{l}62.1 \\
(S D=13.9)\end{array}$ & Affymetrix & $\begin{array}{l}22.4 \mathrm{~mm} \\
(\mathrm{SD}=12.5)\end{array}$ & $\begin{array}{l}84 / 253 \mathrm{LN} \\
\text { metastasis, } 160 \\
\text { node-negative, } 9 \\
\text { unknown node } \\
\text { status }\end{array}$ & $\begin{array}{l}143 \text { no adjuvant } \\
\text { therapy; others } \\
\text { with systemic } \\
\text { adjuvant } \\
\text { therapy, and/or } \\
\text { chemotherapy }\end{array}$ & \\
\hline $\begin{array}{l}\text { Minn and } \\
\text { colleagues } \\
{[61]}\end{array}$ & 82 & $\begin{array}{l}55.8 \\
(S D=13.5)\end{array}$ & Affymetrix & $\begin{array}{l}3.68 \mathrm{~cm} \\
(\mathrm{SD}=1.77 \\
\mathrm{cm})\end{array}$ & $\begin{array}{l}\text { Average } 3.5 \text { (SD } \\
=5.98 \text { ) axillary } \\
\text { LN }\end{array}$ & $\begin{array}{l}\text { Adjuvant } \\
\text { chemotherapy } \\
\text { and/or hormonal } \\
\text { therapy }\end{array}$ & \\
\hline $\begin{array}{l}\text { Richardson } \\
\text { and colleagues } \\
\text { [62] }\end{array}$ & 39 & & Affymetrix & & & & \\
\hline $\begin{array}{l}\text { Saal and } \\
\text { colleagues } \\
\text { [37] }\end{array}$ & 105 & $\begin{array}{l}61 \\
\text { (range } 26 \text { to } \\
77)\end{array}$ & Non-Affymetrix & $\begin{array}{l}27 \mathrm{~mm} \\
\text { (range } 2 \text { to } 50 \\
\mathrm{~mm} \text { ) }\end{array}$ & $\begin{array}{l}65(62 \%) \text { LN- } \\
\text { positive }\end{array}$ & $\begin{array}{l}\text { Treated } \\
\text { uniformly with } 2 \\
\text { years of adjuvant } \\
\text { tamoxifen }\end{array}$ & $\begin{array}{l}\text { Stage II, primary } \\
\text { breast cancer }\end{array}$ \\
\hline $\begin{array}{l}\text { Sotiriou and } \\
\text { colleagues } \\
\text { [63] }\end{array}$ & $\begin{array}{l}119 \\
\text { (KJ125 dataset) }\end{array}$ & $\begin{array}{l}45 \%<50 \\
55 \%>50\end{array}$ & Affymetrix & $\begin{array}{l}61 \%<2 \mathrm{~cm} \\
39 \%>2 \mathrm{~cm}\end{array}$ & LN-negative & $\begin{array}{l}\text { No adjuvant } \\
\text { systemic therapy }\end{array}$ & $\begin{array}{l}34 \text { grade } 1,46 \\
\text { grade } 2,28 \\
\text { grade } 3,17 \text { not } \\
\text { available }\end{array}$ \\
\hline $\begin{array}{l}\text { Turashvili and } \\
\text { colleagues } \\
\text { [32] }\end{array}$ & 10 & & Affymetrix & & & & $\begin{array}{l}3 \text { grade I, } 5 \\
\text { grade II, } 2 \text { grade } \\
\text { IIII }\end{array}$ \\
\hline $\begin{array}{l}\text { van de Vijver } \\
\text { and colleagues } \\
{[64]}\end{array}$ & 295 & $<52$ & Non-Affymetrix & $<5 \mathrm{~cm}$ & $\begin{array}{l}151 \mathrm{LN}- \\
\text { negative, } 144 \\
\text { LN-positive }\end{array}$ & $\begin{array}{l}\text { Modified radical } \\
\text { mastectomy or } \\
\text { breast- } \\
\text { conserving } \\
\text { surgery }\end{array}$ & $\begin{array}{l}\text { Stage I or stage } \\
\text { II breast cancer }\end{array}$ \\
\hline $\begin{array}{l}\text { Wang and } \\
\text { colleagues } \\
\text { [65] }\end{array}$ & 286 & $54(\mathrm{SD}=12)$ & Affymetrix & & LN-negative & $\begin{array}{l}\text { No adjuvant } \\
\text { treatment }\end{array}$ & \\
\hline
\end{tabular}


Table 1 (Continued)

\begin{tabular}{|c|c|c|c|c|c|c|}
\hline $\begin{array}{l}\text { Yu and } \\
\text { colleagues } \\
\text { [38] }\end{array}$ & $\begin{array}{l}96 \text { (only } 68 \text { with } \\
\text { Notch-1 and } \\
\text { survivin data) }\end{array}$ & $55(\mathrm{SD}=10.9)$ & Affymetrix & $\begin{array}{l}37.7 \mathrm{~mm} \\
(\mathrm{SD}=17.9)\end{array}$ & $\begin{array}{l}37.5 \% \text { LN- } \\
\text { negative }\end{array}$ & $\begin{array}{l}2 \text { unknown } \\
\text { grade, } 5 \text { grade I, } \\
26 \text { grade II, } 63 \\
\text { grade III }\end{array}$ \\
\hline $\begin{array}{l}\text { Zhao and } \\
\text { colleagues } \\
{[36]}\end{array}$ & $\begin{array}{l}59 \text { (35 } \\
\text { intraductal } \\
\text { carcinoma, } 17 \\
\text { intralobular } \\
\text { carcinoma; } \\
\text { three from each } \\
\text { with unknown } \\
\text { ER status) }\end{array}$ & $\begin{array}{l}\text { Ductal, } 53 \text { (SD } \\
=15.5) ; \text { lobular, } \\
63.5 \\
(\mathrm{SD}=14.0)\end{array}$ & Non-Affymetrix & & $\begin{array}{l}\text { Ductal, } 16 \mathrm{LN}- \\
\text { positive, } 16 \mathrm{LN}- \\
\text { negative, } 3 \mathrm{LN} \\
\text { unknown; } \\
\text { lobular, } 7 \mathrm{LN}- \\
\text { positive, } 7 \mathrm{LN}- \\
\text { negative, } 4 \mathrm{LN} \\
\text { unknown }\end{array}$ & $\begin{array}{l}\text { Ductal, } 5 \text { grade } \\
\text { I, } 19 \text { grade II, } 11 \\
\text { grade III; lobular, } \\
17 \text { grade II, } 1 \\
\text { grade I }\end{array}$ \\
\hline
\end{tabular}

Sixteen datasets derived from an unbiased search of human breast cancer microarrays on Oncomine were identified that matched the study criteria.

vivin, and keratin-5 differ between ER-negative and ERpositive samples among the different studies.

\section{Cells, reagents and transfections}

The breast adenocarcinoma MDA-MB-231 cell line was obtained from the American Type Culture Collection (Manassas, VA, USA), and was maintained in culture as recommended by the supplier. The cDNA encoding activated NIC was characterized previously [34]. MDA-MB-231 cells were transfected with control plasmid cDNA or NIC cDNA $(2 \mu \mathrm{g})$ using $6 \mu$ LipofectAmine (Invitrogen, Carlsbad, CA, USA) in Opti-Mem medium ( $1 \mathrm{ml}$ ) (Gibco, Carlsbad, CA, USA). The media was changed after 5 hours, and cells were harvested after 24 hours.

The peptidyl $\gamma$-secretase inhibitor z-Leu-Leu-Nle-CHO was purchased from Calbiochem (San Diego, CA, USA), and has been characterized previously [35]. For gene silencing experiments by siRNA, MDA-MB-231 cells were transfected with double-stranded RNA oligonucleotide directed to Notch-1 (pool of three siRNA; Santa Cruz, Santa Cruz, CA, USA), survivin, or control nontargeted sequences using $10 \mu \mathrm{l} \mathrm{HiPerfect}$
(Gibco). Cells under the various conditions were harvested after 48 hours, and were analyzed by western blotting.

\section{Results \\ Expression of Notch-1 and survivin in basal breast cancer}

Recent studies have shown that Notch activation results in increased expression of survivin in basal breast cancer cell lines [35]. To determine whether a similar association occurs in vivo, we examined by immunohistochemistry a panel of basal breast cancer cases for expression of activated Notch-1 (NIC) and survivin. The average age of the nine patients was $52.3 \pm 6.1$ years. All cases were grade 3 tumors with negative protein expression of ER, progesterone receptor, and HER-2, and positive protein expression of keratin $5 / 6$, as assessed by immunohistochemistry. Activated Notch-1 was abundantly expressed in all cases examined of basal breast cancer, and was localized to both the cytosol and nuclei of tumor cells (Figure 1). Survivin was also strongly expressed in all basal breast cancer cases, and was similarly localized to the nuclei and cytosol of the tumor cell population (Figure 1).

Figure 1

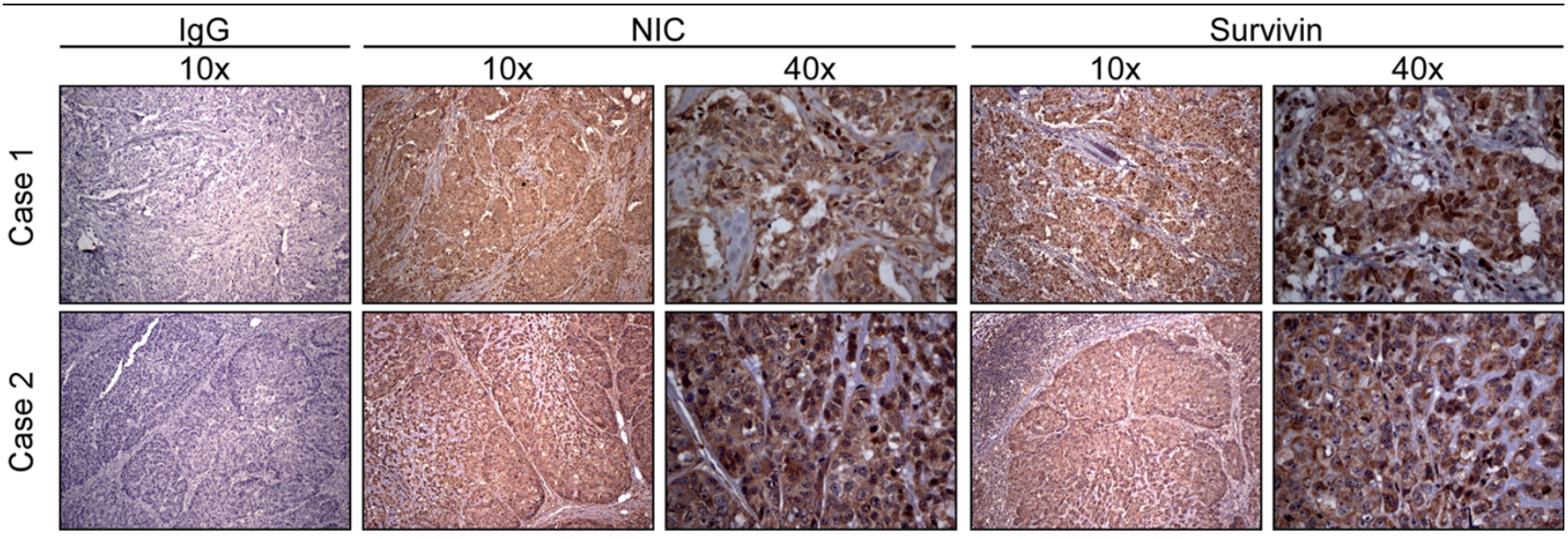

Expression of activated Notch-1 and survivin in basal breast cancer. Representative basal breast cancer cases were analyzed by immunohistochemistry. NIC, Notch-1 intracellular domain. 


\section{Expression of Notch-1 mRNA in breast cancer microarray databases}

We next analyzed the expression of Notch-1 mRNA in an established breast cancer patient cohort. Supervised hierarchical clustering of 232 cases of human breast cancer [25], using intrinsic gene analysis, revealed that higher expression of Notch-1 segregated with basal breast cancer. Other known markers of the disease, including keratin-5, keratin-14, and kit, were also highly correlated with Notch-1 expression $(r \geq 0.58)$ in this cohort (Figure 2).
One hundred and twenty-five patients with associated clinical outcome data were further analyzed. When stratified according to levels of Notch-1 $\log _{2}$ transcript ratios, tumors with the highest quartile of Notch-1 gene expression (first quartile) exhibited abbreviated overall survival with a median survival of 27 months compared with the other groups $(P<0.001$ via the log-rank test) (Figure 3a). Seventy-two percent of tumors in this first quartile (23/32 tumors) were classified as basal breast cancer, and the overall survival of these patients was approximately $50 \%$ lower of that of the remaining population $(P<0.02)$. Conversely, reduced levels of Notch-1 (second to fourth quartiles) were associated with better overall survival

Figure 2

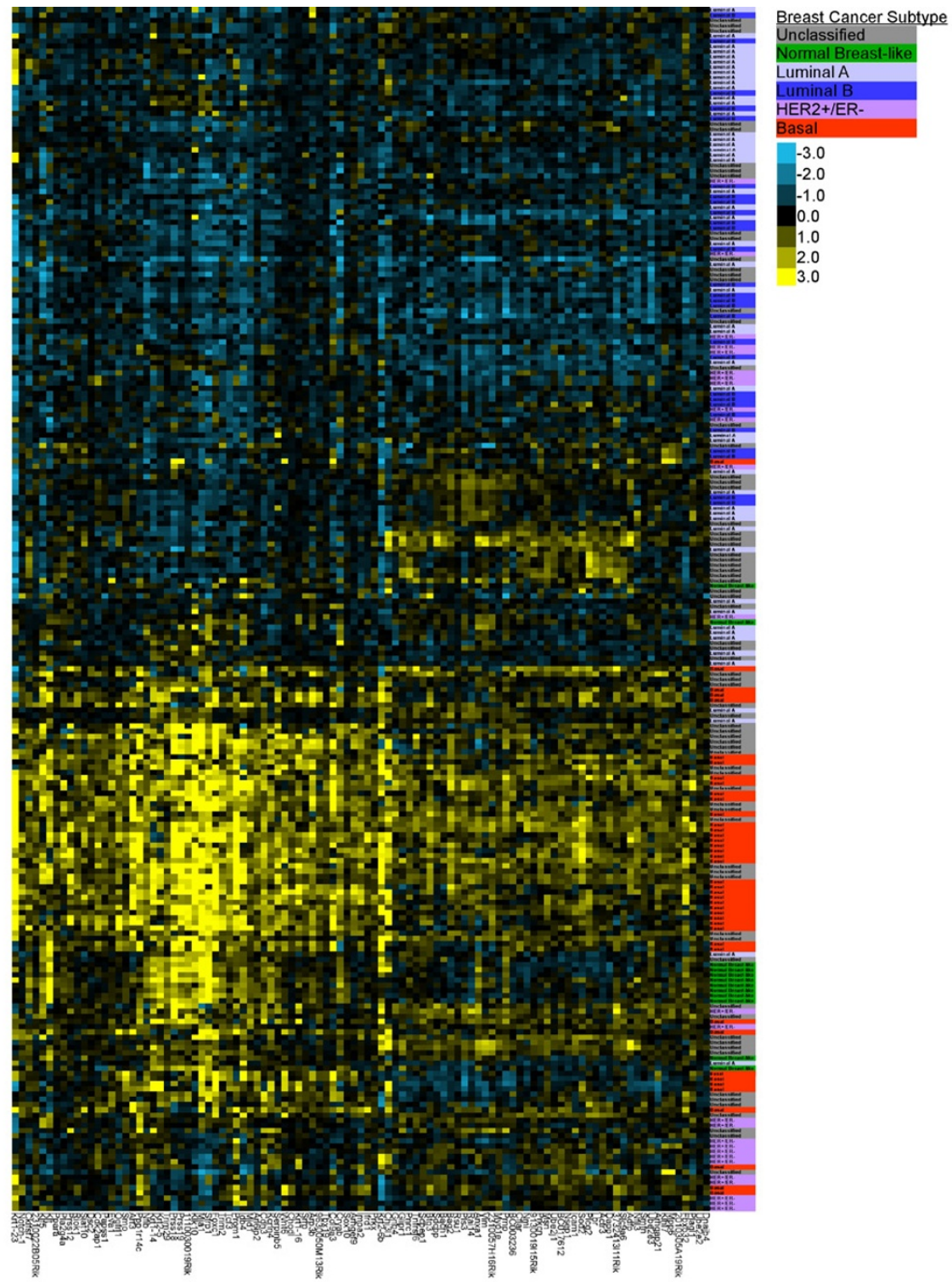

Notch-1 segregates with basal breast cancer. Heat map of 232 cases of breast cancer. Unclassified, gray; normal breast-like, green; luminal A, light blue; luminal B, dark blue; HER-2+/estrogen receptor-negative (ER-), purple; basal, red. 
Figure 3

(a)

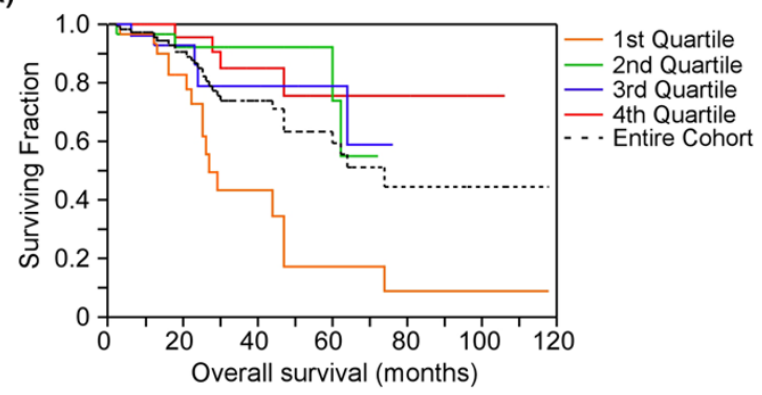

(b)

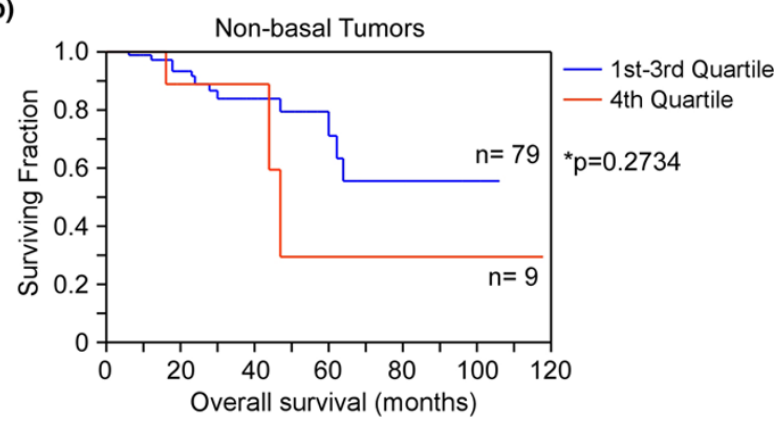

(c)

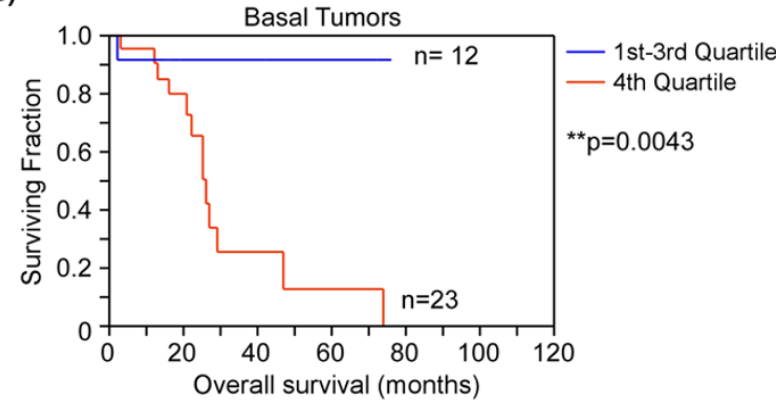

Overall survival. (a) Kaplan-Meier curves of differential overall survival were plotted according to Notch-1 expression in the entire cohort (quartiles). (b) Nonbasal tumors and (c) basal tumors were subgrouped into high Notch-1 expression (fourth quartile) or low Notch-1 expression (first to third quartiles) and were analyzed for overall survival.

(Figure 3a). The percentage of basal breast cancers in these groups was 17\% (second quartile, 5/30 tumors), 20\% (third quartile, $6 / 30$ tumors), and 10\% (fourth quartile, $3 / 31$ tumors), respectively.

The tumors were then segregated based on basal or nonbasal subgroup status and were analyzed for overall survival. In the nonbasal breast tumors, the expression of Notch-1 was not associated with significant differences in overall survival $(P=$ 0.2734) (Figure 3b). In contrast, Notch-1 levels dictated overall survival in basal breast tumors (Figure $3 \mathrm{c}$ ). In this basal subgroup, increased Notch-1 expression (fourth quartile) greatly reduced overall survival to the median of 26 months (Figure 3c). Comparatively, low levels of Notch-1 (first to third quartiles) demonstrated improved overall survival (Figure 3c).

\section{Gene expression correlation in basal breast cancer}

We next carried out a meta-analysis of published microarray datasets to identify genes associated with Notch and potentially implicated in the molecular pathogenesis of basal breast cancer. Based on our recent data [35], we focused on survivin - a mitotic regulator and cell death inhibitor overexpressed in breast cancer [3,21], and associated with unfavorable outcome [2] - and keratin-5 - a marker of basal epithelium, often linked to a progenitor/stem cell phenotype [13].

Fifteen microarray datasets, mostly employing Affymetrix technology, published between 2002 and 2007 met the search criteria (Table 1). The overall median age of patients was 55.2 years. The breast tumors examined were typically $<5 \mathrm{~cm}$, encompassing all grades, and included lymph node-positive and lymph node-negative disease. In one study, separate databases for lobular and ductal breast cancer were examined [36] - bringing the datasets analyzed to a total of 16 . Two studies did not contain downloadable keratin-5 expression data [36,37], and one study contained 68 out of 96 samples with Notch-1 and survivin data and 19 samples with keratin- 5 data [38]. Table 2 presents the descriptive statistics of each cohort with respect to Notch-1, survivin, and keratin-5 relative expression.

\section{A novel dual-gene signature in basal breast cancer} Analysis of 507 ER-negative and 1,356 ER-positive breast cancer patients revealed that keratin-5 associated with ERnegative breast cancers (Figure 4a) in seven out of 13 datasets, and that Notch-1 associated with ER-negative breast cancers in nine out of 16 datasets (Table 2). Pooled estimates of Pearson's correlation coefficient between Notch-1/keratin5 were 0.3315 and 0.2043 for ER-negative and ER-positive breast cancers, respectively $(P=0.04)$ (Figure 4a). Similarly, survivin and keratin-5 co-segregated in ER-negative breast cancer, with a pooled estimate of Pearson's correlation coefficient of 0.1314 for ER-negative breast cancer and of -0.2408 for ER-positive breast cancer $(P<0.0001)$ (Figure 4b). A negative correlation exists between survivin and keratin-5 in ERpositive breast cancers most probably because other transcriptional and nontranscriptional mechanisms are likely to control survivin expression in nonbasal cancers (Figure 4b).

Analysis of 604 ER-negative and 1,463 ER-positive breast cancer patients revealed that survivin segregated with ERnegative tumors (two-tailed $P<0.05$ ) in 12 out of 16 cohorts (Table 2). The Pearson's correlation coefficients between Notch-1 and survivin were 0.1804 and -0.0674 for ER-negative and ER-positive breast cancers, respectively $(P<0.0001)$ (Figure 4c). 
Table 2

\section{Descriptive statistics of studies in the meta-analysis}

\begin{tabular}{|c|c|c|c|c|c|c|c|c|c|c|c|}
\hline \multirow[t]{2}{*}{ Study } & \multirow[t]{2}{*}{ Total $n$} & \multirow[t]{2}{*}{ Subset } & \multicolumn{3}{|c|}{ Survivin } & \multicolumn{3}{|c|}{ Notch-1 } & \multicolumn{3}{|c|}{ Keratin 5} \\
\hline & & & Mean & SEM & $P$ & Mean & SEM & $P$ & Mean & SEM & $P$ \\
\hline \multirow[t]{2}{*}{$\begin{array}{l}\text { Chin and } \\
\text { colleagues [55] }\end{array}$} & 118 & $\begin{array}{l}\text { ER- } \\
(n=43)\end{array}$ & 0.7723 & 0.0815 & $\begin{array}{l}1.353 \times \\
10^{-5}\end{array}$ & 0.7793 & 0.0548 & $\begin{array}{l}2.231 \times \\
10^{-5}\end{array}$ & 0.9844 & 0.1436 & $\begin{array}{l}4.893 \times \\
10^{-6}\end{array}$ \\
\hline & & $\begin{array}{l}\text { ER+ } \\
(n=75)\end{array}$ & 0.3371 & 0.0437 & & 0.5027 & 0.0245 & & 0.1884 & 0.0678 & \\
\hline \multirow[t]{2}{*}{$\begin{array}{l}\text { Desmedt and } \\
\text { colleagues [56] }\end{array}$} & 198 & $\begin{array}{l}\text { ER- } \\
(n=64)\end{array}$ & 0.7238 & 0.0478 & $\begin{array}{l}1.414 \times \\
10^{-8}\end{array}$ & 0.3254 & 0.0389 & $\begin{array}{l}3.951 \times \\
10^{-4}\end{array}$ & 0.6649 & 0.0996 & $\begin{array}{l}1.159 \times \\
10^{-2}\end{array}$ \\
\hline & & $\begin{array}{l}\mathrm{ER}+ \\
(n=134)\end{array}$ & 0.3278 & 0.0460 & & 0.1658 & 0.0193 & & 0.3773 & 0.0507 & \\
\hline \multirow[t]{2}{*}{$\begin{array}{l}\text { Ginestier and } \\
\text { colleagues [57] }\end{array}$} & 55 & $\begin{array}{l}\text { ER- } \\
(n=28)\end{array}$ & 0.7621 & 0.1251 & $\begin{array}{l}9.689 \times \\
10^{-5}\end{array}$ & 1.4343 & 0.0504 & $\begin{array}{l}2.933 \times \\
10^{-4}\end{array}$ & 1.2587 & 0.2116 & $\begin{array}{l}1.219 \times \\
10^{-2}\end{array}$ \\
\hline & & $\begin{array}{l}\mathrm{ER}+ \\
(\mathrm{n}=27)\end{array}$ & 0.4959 & 0.0954 & & 1.1536 & 0.0520 & & 0.5842 & 0.1492 & \\
\hline \multirow[t]{2}{*}{$\begin{array}{l}\text { Hess and } \\
\text { colleagues [58] }\end{array}$} & 133 & $\begin{array}{l}\text { ER- } \\
(n=51)\end{array}$ & 0.0776 & 0.0451 & $\begin{array}{l}2.071 \times \\
10^{-3}\end{array}$ & 0.2169 & 0.0454 & $\begin{array}{l}1.203 \times \\
10^{-1}\end{array}$ & 0.5110 & 0.1706 & $\begin{array}{l}1.165 \times \\
10^{-4}\end{array}$ \\
\hline & & $\begin{array}{l}\text { ER+ } \\
(n=82)\end{array}$ & -0.0956 & 0.0309 & & 0.1238 & 0.0384 & & -0.2216 & 0.0480 & \\
\hline \multirow[t]{2}{*}{$\begin{array}{l}\text { Ivshina and } \\
\text { colleagues [59] }\end{array}$} & $249^{a}$ & $\begin{array}{l}\text { ER- } \\
(n=34)\end{array}$ & 0.4877 & 0.0847 & $\begin{array}{l}1.064 \mathrm{e} \times \\
10^{-7}\end{array}$ & 0.3819 & 0.0589 & $\begin{array}{l}1.643 \times \\
10^{-2}\end{array}$ & 0.7071 & 0.1683 & $\begin{array}{l}1.403 \times \\
10^{-1}\end{array}$ \\
\hline & & $\begin{array}{l}\mathrm{ER}+ \\
(\mathrm{n}=211)\end{array}$ & -0.0950 & 0.0408 & & 0.2299 & 0.0137 & & 0.4438 & 0.0479 & \\
\hline \multirow[t]{2}{*}{$\begin{array}{l}\text { Miller and } \\
\text { colleagues [60] }\end{array}$} & 251 & $\begin{array}{l}\text { ER- } \\
(n=34)\end{array}$ & 0.3701 & 0.0681 & $\begin{array}{l}2.780 \times \\
10^{-8}\end{array}$ & 0.3011 & 0.0443 & $\begin{array}{l}2.073 \times \\
10^{-2}\end{array}$ & 0.4714 & 0.1310 & $\begin{array}{l}2.638 \times \\
10^{-1}\end{array}$ \\
\hline & & $\begin{array}{l}\text { ER+ } \\
(n=213)\end{array}$ & -0.1337 & 0.0382 & & 0.1905 & 0.0113 & & 0.3165 & 0.0389 & \\
\hline \multirow[t]{2}{*}{$\begin{array}{l}\text { Minn and } \\
\text { colleagues [61] }\end{array}$} & 82 & $\begin{array}{l}\text { ER- } \\
(n=42)\end{array}$ & 0.1969 & 0.0719 & $\begin{array}{l}1.809 \times \\
10^{-4}\end{array}$ & 0.4515 & 0.0529 & $\begin{array}{l}7.897 \times \\
10^{-5}\end{array}$ & 1.1060 & 0.1311 & $\begin{array}{l}2.391 \times \\
10^{-6}\end{array}$ \\
\hline & & $\begin{array}{l}\text { ER+ } \\
(n=57)\end{array}$ & -0.1821 & 0.0652 & & 0.2036 & 0.0247 & & 0.2624 & 0.1028 & \\
\hline \multirow[t]{2}{*}{$\begin{array}{l}\text { Richardson and } \\
\text { colleagues [62] }\end{array}$} & 39 & $\begin{array}{l}\text { ER- } \\
(n=24)\end{array}$ & -0.1141 & 0.1363 & $\begin{array}{l}6.374 \times \\
10^{-3}\end{array}$ & 1.1360 & 0.0621 & $\begin{array}{l}1.216 \times \\
10^{-1}\end{array}$ & 1.1878 & 0.1436 & $\begin{array}{l}4.670 \mathrm{e} \times \\
10^{-3}\end{array}$ \\
\hline & & $\begin{array}{l}\mathrm{ER}+ \\
(n=15)\end{array}$ & -0.6187 & 0.1089 & & 1.0139 & 0.0457 & & 0.6193 & 0.1225 & \\
\hline \multirow[t]{2}{*}{$\begin{array}{l}\text { Saal and } \\
\text { colleagues [37] }\end{array}$} & 105 & $\begin{array}{l}\text { ER- } \\
(n=60)\end{array}$ & -1.3798 & 0.1075 & $\begin{array}{l}5.143 \times \\
10^{-6}\end{array}$ & 0.2043 & 0.0756 & $\begin{array}{l}3.033 \times \\
10^{-3}\end{array}$ & & & \\
\hline & & $\begin{array}{l}\text { ER+ } \\
(n=45)\end{array}$ & -2.1290 & 0.1121 & & -0.1145 & 0.0728 & & & & \\
\hline
\end{tabular}




\begin{tabular}{|c|c|c|c|c|c|c|c|c|c|c|c|}
\hline \multirow[t]{2}{*}{$\begin{array}{l}\text { Sotiriou and } \\
\text { colleagues [63] }\end{array}$} & 119 & $\begin{array}{l}\text { ER- } \\
(n=34)\end{array}$ & 0.4834 & 0.0320 & $\begin{array}{l}2.528 \times \\
10^{-3}\end{array}$ & 0.2702 & 0.0565 & $\begin{array}{l}1.323 \times \\
10^{-4}\end{array}$ & 0.9849 & 0.1107 & $\begin{array}{l}9.396 \times \\
10^{-3}\end{array}$ \\
\hline & & $\begin{array}{l}\text { ER+ } \\
(n=85)\end{array}$ & 0.3691 & 0.0166 & & 0.0181 & 0.0196 & & 0.6560 & 0.0499 & \\
\hline \multirow[t]{2}{*}{ Turashvili [32] } & 10 & ER- $(n=3)$ & 0.1268 & 0.1688 & $\begin{array}{l}2.533 \times \\
10^{-1}\end{array}$ & 1.1991 & 0.1243 & $\begin{array}{l}3.082 \times \\
10^{-1}\end{array}$ & 0.6117 & 0.3735 & $\begin{array}{l}6.750 \times \\
10^{-1}\end{array}$ \\
\hline & & $\mathrm{ER}+(\mathrm{n}=7)$ & -0.2686 & 0.2733 & & 1.0239 & 0.0709 & & 0.3655 & 0.4358 & \\
\hline \multirow{2}{*}{$\begin{array}{l}\text { van de Vijver } \\
\text { and colleagues } \\
\text { [64] }\end{array}$} & 295 & $\begin{array}{l}\text { ER- } \\
(n=69)\end{array}$ & 0.3719 & 0.2218 & $\begin{array}{l}1.847 \times \\
10^{-12}\end{array}$ & 0.6277 & 0.1148 & $\begin{array}{l}1.418 \times \\
10^{-10}\end{array}$ & -0.7917 & 0.4073 & $\begin{array}{l}1.748 \times \\
10^{-5}\end{array}$ \\
\hline & & $\begin{array}{l}\text { ER+ } \\
(n=226)\end{array}$ & -1.7301 & 0.1580 & & -0.2900 & 0.0590 & & -2.8083 & 0.1822 & \\
\hline \multirow[t]{2}{*}{$\begin{array}{l}\text { Wang and } \\
\text { colleagues [65] }\end{array}$} & 286 & $\begin{array}{l}\text { ER- } \\
(n=77)\end{array}$ & 0.0902 & 0.0459 & $\begin{array}{l}2.284 \times \\
10^{-8}\end{array}$ & 0.4139 & 0.0282 & $\begin{array}{l}2.255 \times \\
10^{-11}\end{array}$ & 0.8906 & 0.0819 & $\begin{array}{l}3.242 \times \\
10^{-7}\end{array}$ \\
\hline & & $\begin{array}{l}\text { ER+ } \\
(n=209)\end{array}$ & -0.2387 & 0.0318 & & 0.1784 & 0.0151 & & 0.3844 & 0.0459 & \\
\hline \multirow[t]{2}{*}{$\begin{array}{l}\text { Yu and } \\
\text { colleagues [38] }\end{array}$} & $68(19)$ & $\begin{array}{l}\text { ER- } \\
(n=15)\end{array}$ & -0.2546 & 0.0874 & $\begin{array}{l}1.689 \times \\
10^{-1}\end{array}$ & -0.2712 & 0.1090 & $\begin{array}{l}1.946 \times \\
10^{-4}\end{array}$ & $1.8394^{*}$ & $0.2312^{*}$ & $\begin{array}{l}2.280 \times \\
10^{-2} \text { * }\end{array}$ \\
\hline & & $E R+(n=4)$ & -0.4225 & 0.0831 & & 0.7625 & 0.0431 & & $0.9196^{*}$ & $0.2431^{*}$ & \\
\hline \multirow{2}{*}{$\begin{array}{l}\text { Zhao and } \\
\text { colleagues } \\
\text { (lobular) [36] }\end{array}$} & 16 & ER- $(n=4)$ & -2.4418 & 0.2721 & $\begin{array}{l}6.851 \times \\
10^{-1}\end{array}$ & 0.0416 & 0.4079 & $\begin{array}{l}7.011 \times \\
10^{-1}\end{array}$ & & & \\
\hline & & $\begin{array}{l}\mathrm{ER}+ \\
(n=12)\end{array}$ & -2.3108 & 0.1269 & & -0.1367 & 0.1083 & & & & \\
\hline \multirow{2}{*}{$\begin{array}{l}\text { Zhao and } \\
\text { colleagues } \\
\text { (ductal) [36] }\end{array}$} & 34 & $\begin{array}{l}\text { ER- } \\
(n=11)\end{array}$ & -1.4613 & 0.2938 & $\begin{array}{l}1.440 \times \\
10^{-1}\end{array}$ & 0.3298 & 0.3722 & $\begin{array}{l}1.769 \times \\
10^{-1}\end{array}$ & & & \\
\hline & & $\begin{array}{l}\mathrm{ER}+ \\
(n=23)\end{array}$ & -2.0013 & 0.1981 & & -0.2272 & 0.1104 & & & & \\
\hline
\end{tabular}

Mean, standard error of mean (SEM), and $P$ value between estrogen receptor-negative (ER-) and estrogen receptor-positive (ER+) breast cancers are presented for Notch-1, survivin, and keratin-5 expression in the analyzed datasets. aUppsala cohort. ${ }^{\star}$ Subset of samples with keratin-5 data.

\section{Notch-1 regulation of survivin expression}

Consistent with the model presented above, recent studies have shown that survivin may function as a direct transcriptional target of Notch-1, thus controlling mitotic transition and resistance to apoptosis in breast cancer [35]. In agreement with these data, transfection of ER-negative breast cancer MDA-MB-231 cells with NIC resulted in increased survivin expression, as determined by western blotting, whereas acute siRNA silencing of Notch was associated with reduced survivin levels and induction of apoptosis (data not shown). Similarly, inhibition of Notch signaling by a pharmacologic inhibitor of $\gamma$-secretase suppressed survivin gene expression (data not shown), validating the identity of survivin as a direct transcriptional target of Notch in breast cancer cells [35].

\section{Discussion}

In the present study, we have shown that Notch-1 is preferentially expressed in breast cancer, as compared with normal tissues, segregates with basal disease, and correlates with abbreviated survival. In a meta-analysis of multiple, independent microarray datasets, Notch-1, survivin, and keratin-5 selectively co-associated with ER-negative versus ER-positive breast cancer patients. Consistent with recent observations [35], survivin was validated as a direct transcriptional target of Notch in model ER-negative breast cancer cells. 
(a)

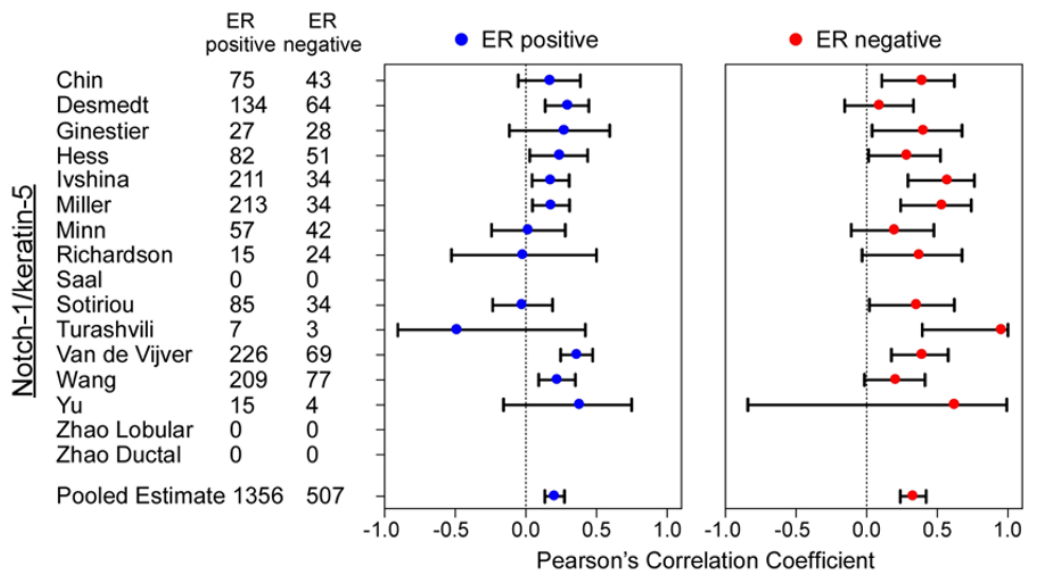

(b)

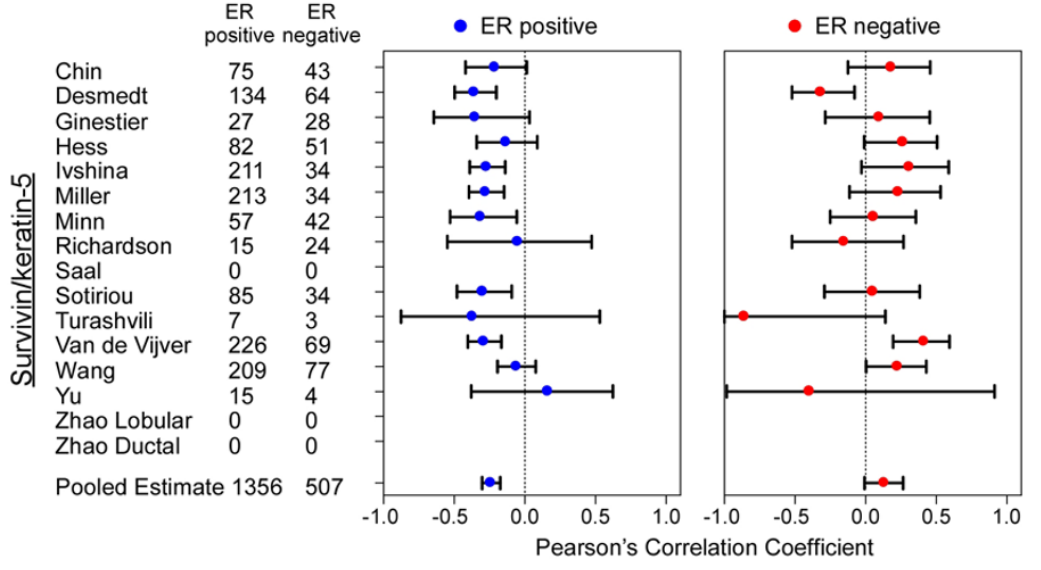

(c)

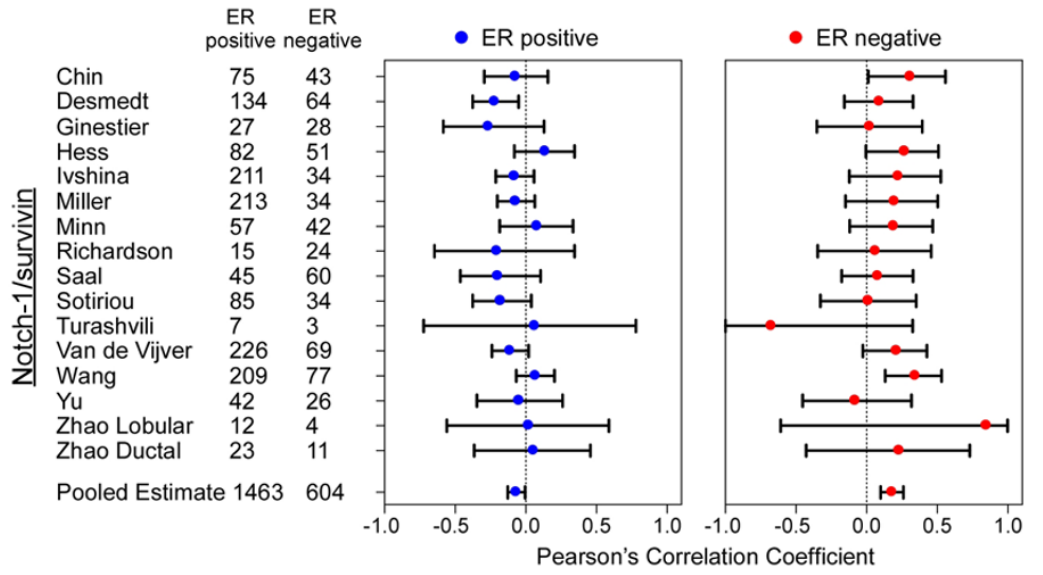

Co-segregation of Notch-1, survivin, and keratin-5 in breast cancer. Pearson's correlation coefficient and the 95\% confidence interval were calculated from the analysis of individual datasets. (a) Notch-1/keratin-5. (b) Survivin/keratin-5. (c) Notch-1/survivin. For study details, see Table 2. ER, estrogen receptor.

These findings add to an in-depth molecular classification of breast cancer [4] - and in particular basal breast cancer, a disease variant that still poses significant therapeutic challenges. In addition to high-risk genetics [7,8] and aggressive histologic features [5], it has been speculated that basal breast cancer may originate from a progenitor/stem cell compartment in the basal mammary epithelium. This is consistent with a proposed role for Notch in mammary progenitor cell differentiation and maintenance [39], and potentially in the early events of their transformation [40]. Such a pathway may not be exclu- 
sively limited to breast cancer [20], given that deregulated Notch signaling has been implicated as a driver of disparate malignancies [15], as promoting aberrant cell cycle progression [41], and associated with unfavorable outcome [18].

In this context, survivin appears ideally suited to function as a pleiotropic, direct Notch effector gene in clinically aggressive breast cancer [2]. At the molecular level, this involves occupancy of discrete RPB-Jא binding element(s) in the survivin promoter upon Notch activation, which results in transcriptional upregulation of survivin levels, inhibition of apoptosis, and acceleration of mitotic transitions selectively in ER-negative breast cancer cells [35]. Whether deregulation of a Notch-survivin signaling axis is preferentially operative in a progenitor/stem cell compartment is currently not known.

Intriguing, however, is that another developmental gene expression pathway (that is, $\mathrm{Wnt} / \beta$-catenin) has been implicated in controlling survivin levels in intestinal crypt progenitor cells, potentially contributing to colon cancer [42], and that survivin expression been consistently associated with stemness gene signatures of mesenchymal [43], neuronal [44], and skin [45] progenitor cells. Results of conditional knockout studies appear to support this model, as heterozygous deletion of survivin produced complete bone marrow ablation, loss of hematopoietic progenitor/stem cells, and rapid animal mortality [22]. This pathway may have a clear link to human disease, as lineage-specific methylation and silencing of the survivin gene has been linked to bone marrow depletion in myelodsyplastic syndrome [46]. With respect to breast cancer, Notch-dependent upregulation of survivin [35] may broadly suppress apoptosis, deregulate cell cycle progression [21], and ultimately promote resistance to mainstay therapeutic agents in this disease, such as taxanes [47] and DNA damaging agents [48].

Although the diagnosis of triple-negative, basal breast cancer is straightforward [6], these patients continue to pose therapeutic challenges for the aggressive nature of the disease, which is prone to relapse, and the lack of appropriate, molecularly targeted agents [10]. Based on the findings presented herein, it may be possible to envision antagonists of Notch [49] and of survivin [21] as potential molecular therapy for basal breast cancer patients. Agents that interfere with Notch signaling inhibit the enzyme $\gamma$-secretase, which is responsible for the activating intracellular cleavage of Notch upon ligand binding at the cell surface [15]. Despite concerns of specificity [50] and potential intestinal toxicity [51], $\gamma$-secretase inhibitor molecules are being tested as molecular therapy for leukemic patients harboring activating mutations in Notch [49]. In our recent studies, systemic administration of a peptidyl $\gamma$-secretase inhibitor significantly inhibited breast cancer growth in vivo, and almost completely abolished metastatic dissemination, with no detectable organ or systemic toxicity [35]. Antagonists of survivin are also available in the clinic, producing encouraging patient responses and manageable toxicity in early-phase clinical trials [21].

In summary, we have extended recent in vitro observations [35] and have validated the existence of a functional Notch-1/ survivin signaling axis, in vivo, selectively in patients with basal breast cancer. Targeting Notch-1 signaling in model breast cancer cells lowered survivin levels, resulting in pronounced anti-tumor effects [35]. Taken together with the stringent correlation reported here across disparate tumor series, in vivo, this observation raises the possibility that basal breast cancer cells may selectively become dependent on, or addicted to, Notch/survivin signaling for their maintenance [52]. Although it is unclear to what extent oncogene addiction maintains the malignant phenotype in vivo [53], antagonists of such pathways have produced impressive clinical responses, at least in certain patient subsets [54]. A similar rationale may be envisioned here for targeting Notch and survivin in basal breast cancer patients, especially if this pathway can be disabled in a progenitor/stem cell compartment, acting as a potential disease reservoir contributing to a high incidence of relapses.

\section{Conclusion}

Expression of Notch-1 and survivin segregates with clinically aggressive and recurrence-prone basal breast cancer. Antagonists of these signaling pathways may be considered as targeted, novel molecular therapy of basal breast cancer.

\section{Competing interests}

The authors declare that they have no competing interests.

\section{Authors' contributions}

CWL, JP, and MG carried out experiments of survivin and Notch expression and function in breast cancer as well as immunohistochemical analysis in primary normal and tumor samples. KS performed the hierarchical clustering experiments. QL and $\mathrm{C}-\mathrm{CH}$ provided statistical evaluation and interpretation of the microarray and Pearson analysis data. AK analyzed the immunohistochemistry of human breast tumor samples and provided clinical and pathological data. DCA participated in the design and coordination of the study. CWL and DCA wrote the paper. All authors read and approved the final manuscript.

\section{Acknowledgements}

The present work is supported by grants from the National Institutes of Health: CA132622 (CWL), and HL54131, CA90917, and CA78810 (DCA).

\section{References}

1. Liu R, Wang X, Chen GY, Dalerba P, Gurney A, Hoey T, Sherlock G, Lewicki J, Shedden K, Clarke MF: The prognostic role of a gene signature from tumorigenic breast-cancer cells. N Engl J Med 2007, 356:217-226.

2. Paik S, Shak S, Tang G, Kim C, Baker J, Cronin M, Baehner FL, Walker MG, Watson D, Park T, Hiller W, Fisher ER, Wickerham $\mathrm{DL}$, Bryant J, Wolmark N: A multigene assay to predict recur- 
rence of tamoxifen-treated, node-negative breast cancer. $N$ Engl J Med 2004, 351:2817-2826.

3. van't Veer LJ, Dai H, Vijver MJ van de, He YD, Hart AA, Mao M, Peterse HL, Kooy K van der, Marton MJ, Witteveen AT, Schreiber GJ, Kerkhoven RM, Roberts C, Linsley PS, Bernards R, Friend SH: Gene expression profiling predicts clinical outcome of breast cancer. Nature 2002, 415:530-536.

4. Sotiriou C, Piccart MJ: Taking gene-expression profiling to the clinic: when will molecular signatures become relevant to patient care? Nat Rev Cancer 2007, 7:545-553.

5. Da Silva L, Clarke C, Lakhani SR: Demystifying basal-like breast carcinomas. J Clin Pathol 2007, 60:1328-1332.

6. Nielsen TO, Hsu FD, Jensen K, Cheang M, Karaca G, Hu Z, Hernandez-Boussard T, Livasy C, Cowan D, Dressler L, Akslen LA, Ragaz J, Gown AM, Gilks CB, Rijn M van de, Perou CM: Immunohistochemical and clinical characterization of the basal-like subtype of invasive breast carcinoma. Clin Cancer Res 2004, 10:5367-5374

7. Perou CM, Sorlie T, Eisen MB, Rijn M van de, Jeffrey SS, Rees CA, Pollack JR, Ross DT, Johnsen H, Akslen LA, Fluge O, Pergamenschikov A, Williams C, Zhu SX, Lonning PE, Borresen-Dale AL, Brown PO, Botstein D: Molecular portraits of human breast tumours. Nature 2000, 406:747-752.

8. Sotiriou C, Neo SY, McShane LM, Korn EL, Long PM, Jazaeri A, Martiat P, Fox SB, Harris AL, Liu ET: Breast cancer classification and prognosis based on gene expression profiles from a population-based study. Proc Natl Acad Sci USA 2003, 100:10393-10398.

9. Sorlie T, Perou CM, Tibshirani R, Aas T, Geisler S, Johnsen H, Hastie T, Eisen MB, Rijn M van de, Jeffrey SS, Thorsen T, Quist H, Matese JC, Brown PO, Botstein D, Eystein Lonning P, BorresenDale AL: Gene expression patterns of breast carcinomas distinguish tumor subclasses with clinical implications. Proc Natl Acad Sci USA 2001, 98:10869-10874.

10. Cleator S, Heller W, Coombes RC: Triple-negative breast cancer: therapeutic options. Lancet Oncol 2007, 8:235-244.

11. Baselga J, Albanell J, Ruiz A, Lluch A, Gascon P, Guillem V, Gonzalez S, Sauleda S, Marimon I, Tabernero JM, Koehler MT, Rojo F: Phase II and tumor pharmacodynamic study of gefitinib in patients with advanced breast cancer. J Clin Oncol 2005, 23:5323-5333.

12. Carey LA, Dees EC, Sawyer L, Gatti L, Moore DT, Collichio F, Ollila DW, Sartor Cl, Graham ML, Perou CM: The triple negative paradox: primary tumor chemosensitivity of breast cancer subtypes. Clin Cancer Res 2007, 13:2329-2334.

13. Dontu G, El-Ashry D, Wicha MS: Breast cancer, stem/progenitor cells and the estrogen receptor. Trends Endocrinol Metab 2004, 15:193-197.

14. Clevers $\mathrm{H}:$ Wnt/beta-catenin signaling in development and disease. Cell 2006, 127:469-480.

15. Bray SJ: Notch signalling: a simple pathway becomes complex. Nat Rev Mol Cell Biol 2006, 7:678-689.

16. Buono KD, Robinson GW, Martin C, Shi S, Stanley P, Tanigaki K, Honjo T, Hennighausen L: The canonical Notch/RBP-J signaling pathway controls the balance of cell lineages in mammary epithelium during pregnancy. Dev Biol 2006, 293:565-580.

17. Sansone $P$, Storci G, Tavolari S, Guarnieri T, Giovannini C, Taffurelli M, Ceccarelli C, Santini D, Paterini P, Marcu KB, Chieco $\mathrm{P}$, Bonafe M: IL-6 triggers malignant features in mammospheres from human ductal breast carcinoma and normal mammary gland. J Clin Invest 2007, 117:3988-4002.

18. Reedijk M, Odorcic S, Chang L, Zhang H, Miller N, McCready DR, Lockwood G, Egan SE: High-level coexpression of JAG1 and NOTCH1 is observed in human breast cancer and is associated with poor overall survival. Cancer Res 2005, 65:8530-8537.

19. Rizzo P, Miao H, D'Souza G, Osipo C, Yun J, Zhao H, Mascarenhas J, Wyatt D, Antico G, Hao L, Yao K, Rajan P, Hicks C, Siziopikou K, Selvaggi S, Bashir A, Bhandari D, Marchese A, Lendahl U, Qin J-Z, Tonetti DA, Albain K, Nickoloff BJ, Miele L: Cross-talk between Notch and the Estrogen Receptor in Breast Cancer Suggests Novel Therapeutic Approaches. Cancer Res 2008, 68:5226-5235

20. Stylianou S, Clarke RB, Brennan K: Aberrant activation of notch signaling in human breast cancer. Cancer Res 2006, 66:1517-1525.
21. Altieri DC: Survivin, cancer networks and pathway-directed drug discovery. Nat Rev Cancer 2008, 8:61-70.

22. Leung CG, Xu Y, Mularski B, Liu H, Gurbuxani S, Crispino JD: Requirements for survivin in terminal differentiation of erythroid cells and maintenance of hematopoietic stem and progenitor cells. J Exp Med 2007, 204:1603-1611.

23. Dohi T, Beltrami E, Wall NR, Plescia J, Altieri DC: Mitochondrial survivin inhibits apoptosis and promotes tumorigenesis. $J$ Clin Invest 2004, 114:1117-1127.

24. University of North Carolina Microarray Database [https:// genome.unc.edu]

25. Herschkowitz J, Simin K, Weigman VJ, Mikaelian I, Usary J, Hu Z, Rasmussen KE, Jones LP, Assefnia S, Chandrasekharan S, Backlund MG, Yin Y, Khramtsov Al, Bastein R, Quackenbush J, Glazer RI, Brown PH, Green JE, Kopelovich L, Furth PA, Palazzo JP, Olopade OI, Bernard PS, Churchill GA, Van Dyke T, Perou CM: Identification of conserved gene expression features between murine mammary carcinoma models and human breast tumors. Genome Biol 2007, 8:R76.

26. Eisen MB, Spellman PT, Brown PO, Botstein D: Cluster analysis and display of genome-wide expression patterns. Proc Natl Acad Sci USA 1998, 95:14863-14868.

27. Saldanha AJ: Java Treeview - extensible visualization of microarray data. Bioinformatics 2004, 20:3246-3248.

28. SAS Institute JMP Software [http://www.jmp.com

29. Oncomine [http://www.oncomine.org]

30. Rhodes DR, Yu J, Shanker K, Deshpande N, Varambally R, Ghosh D, Barrette T, Pandey A, Chinnaiyan AM: ONCOMINE: a cancer microarray database and integrated data-mining platform. Neoplasia 2004, 6:1-6

31. Kleibaum DG, Kupper LL, Muller KE, Nizam A: Applied regression analysis and other multivariable methods. Pacific Grove, CA: Duxbury Press; 1998:96-98.

32. Turashvili G, Bouchal J, Baumforth K, Wei W, Dziechciarkova M, Ehrmann J, Klein J, Fridman E, Skarda J, Srovnal J, Hajduch M, Murray $\mathrm{P}, \mathrm{Kolar} Z$ : Novel markers for differentiation of lobular and ductal invasive breast carcinomas by laser microdissection and microarray analysis. BMC Cancer 2007, 7:55.

33. DerSimonian R, Laird N: Meta-analysis in clinical trials. Control Clin Trials 1986, 7:177-188.

34. Xia F, Altieri DC: Mitosis-independent survivin gene expression in vivo and regulation by p53. Cancer Res 2006, 66:3392-3395.

35. Lee CW, Raskett CM, Prudovsky I, Altieri DC: Molecular Dependence of Estrogen Receptor-Negative Breast Cancer on a Notch-Survivin Signaling Axis. Cancer Res 2008, 68:5273-5281.

36. Zhao H, Langerod A, Ji Y, Nowels KW, Nesland JM, Tibshirani R, Bukholm IK, Karesen R, Botstein D, Borresen-Dale AL, Jeffrey SS: Different gene expression patterns in invasive lobular and ductal carcinomas of the breast. Mol Biol Cell 2004, 15:2523-2536

37. Saal LH, Johansson P, Holm K, Gruvberger-Saal SK, She QB Maurer M, Koujak S, Ferrando AA, Malmstrom P, Memeo L, Isola J, Bendahl PO, Rosen N, Hibshoosh H, Ringner M, Borg A, Parsons $\mathrm{R}$ : Poor prognosis in carcinoma is associated with a gene expression signature of aberrant PTEN tumor suppressor pathway activity. Proc Natl Acad Sci USA 2007, 104:7564-7569.

38. Yu K, Ganesan K, Miller LD, Tan P: A modular analysis of breast cancer reveals a novel low-grade molecular signature in estrogen receptor-positive tumors. Clin Cancer Res 2006, 12:3288-3296

39. Raouf A, Zhao Y, To K, Stingl J, Delaney A, Barbara M, Iscove N, Jones S, McKinney S, Emerman J, Aparicio S, Marra M, Eaves C: Transcriptome analysis of the normal human mammary cell commitment and differentiation process. Cell Stem Cell 2008 3:109-118.

40. Farnie G, Clarke RB, Spence K, Pinnock N, Brennan K, Anderson $\mathrm{NG}$, Bundred NJ: Novel cell culture technique for primary ductal carcinoma in situ: role of Notch and epidermal growth factor receptor signaling pathways. I Natl Cancer Inst 2007, 99:616-627.

41. Ronchini C, Capobianco AJ: Induction of cyclin D1 transcription and CDK2 activity by Notch(ic): implication for cell cycle disruption in transformation by Notch(ic). Mol Cell Biol 2001, 21:5925-5934. 
42. Kim PJ, Plescia J, Clevers H, Fearon ER, Altieri DC: Survivin and molecular pathogenesis of colorectal cancer. Lancet 2003, 362:205-209.

43. Taubert H, Wurl $P$, Greither T, Kappler M, Bache M, Bartel F, Kehlen A, Lautenschlager C, Harris LC, Kaushal D, Fussel S, Meye A, Bohnke A, Schmidt H, Holzhausen HJ, Hauptmann S: Stem cellassociated genes are extremely poor prognostic factors for soft-tissue sarcoma patients. Oncogene 2007, 26:7170-7174.

44. Pennartz S, Belvindrah R, Tomiuk S, Zimmer C, Hofmann K, Conradt $\mathrm{M}$, Bosio $\mathrm{A}$, Cremer $\mathrm{H}$ : Purification of neuronal precursors from the adult mouse brain: comprehensive gene expression analysis provides new insights into the control of cell migration, differentiation, and homeostasis. Mol Cell Neurosci 2004 , 25:692-706.

45. Marconi A, Dallaglio K, Lotti R, Vaschieri C, Truzzi F, Fantini F, Pincelli C: Survivin identifies keratinocyte stem cells and it is down-regulated by anti-\{beta\} 1 integrin during anoikis. Stem Cells 2006, 25:149-155.

46. Hopfer O, Komor M, Koehler IS, Schulze M, Hoelzer D, Thiel E, Hofmann WK: DNA methylation profiling of myelodysplastic syndrome hematopoietic progenitor cells during in vitro lineage-specific differentiation. Exp Hemato/ 2007, 35:712-723.

47. O'Connor DS, Wall NR, Porter AC, Altieri DC: A p34(cdc2) survival checkpoint in cancer. Cancer Cell 2002, 2:43-54.

48. Ghosh JC, Dohi T, Raskett CM, Kowalik TF, Altieri DC: Activated checkpoint kinase 2 provides a survival signal for tumor cells. Cancer Res 2006, 66:11576-11579.

49. Shih le $M$, Wang TL: Notch signaling, gamma-secretase inhibitors, and cancer therapy. Cancer Res 2007, 67:1879-1882.

50. Fortini ME: Gamma-secretase-mediated proteolysis in cellsurface-receptor signalling. Nat Rev Mol Cell Biol 2002, 3:673-684.

51. Wong GT, Manfra D, Poulet FM, Zhang Q, Josien H, Bara T, Engstrom L, Pinzon-Ortiz M, Fine JS, Lee HJ, Zhang L, Higgins GA, Parker EM: Chronic treatment with the gamma-secretase inhibitor LY-411,575 inhibits beta-amyloid peptide production and alters lymphopoiesis and intestinal cell differentiation. J Biol Chem 2004, 279:12876-12882.

52. Weinstein IB, Joe AK: Mechanisms of disease: Oncogene addiction - a rationale for molecular targeting in cancer therapy. Nat Clin Pract Oncol 2006, 3:448-457.

53. Jonkers J, Berns A: Oncogene addiction; Sometimes a temporary slavery. Cancer Cell 2004, 6:535-538.

54. Sharma SV, Bell DW, Settleman J, Haber DA: Epidermal growth factor receptor mutations in lung cancer. Nat Rev Cancer 2007, 7:169-181.

55. Chin K, DeVries S, Fridlyand J, Spellman PT, Roydasgupta R, Kuo WL, Lapuk A, Neve RM, Oian Z, Ryder T, Chen F, Feiler H, Tokuyasu T, Kingsley C, Dairkee S, Meng Z, Chew K, Pinkel D, Jain A, Ljung BM, Esserman L, Albertson DG, Waldman FM, Gray JW: Genomic and transcriptional aberrations linked to breast cancer pathophysiologies. Cancer Cell 2006, 10:529-541.

56. Desmedt C, Piette F, Loi S, Wang Y, Lallemand F, Haibe-Kains B, Viale G, Delorenzi M, Zhang Y, d'Assignies MS, Bergh J, Lidereau R, Ellis P, Harris AL, Klijn JG, Foekens JA, Cardoso F, Piccart MJ, Buyse M, Sotiriou C: Strong time dependence of the 76-gene prognostic signature for node-negative breast cancer patients in the TRANSBIG multicenter independent validation series. Clin Cancer Res 2007, 13:3207-3214.

57. Ginestier C, Cervera N, Finetti P, Esteyries S, Esterni B, Adelaide $J$, Xerri L, Viens P, Jacquemier J, Charafe-Jauffret E, Chaffanet M, Birnbaum D, Bertucci F: Prognosis and gene expression profiling of 20q13-amplified breast cancers. Clin Cancer Res 2006, 12:4533-4544.

58. Hess KR, Anderson K, Symmans WF, Valero V, Ibrahim N, Mejia JA, Booser D, Theriault RL, Buzdar AU, Dempsey PJ, Rouzier R, Sneige N, Ross JS, Vidaurre T, Gomez HL, Hortobagyi GN, Pusztai $\mathrm{L}$ : Pharmacogenomic predictor of sensitivity to preoperative chemotherapy with paclitaxel and fluorouracil, doxorubicin, and cyclophosphamide in breast cancer. J Clin Oncol 2006, 24:4236-4244.

59. Ivshina AV, George J, Senko O, Mow B, Putti TC, Smeds J, Lindahl $T$, Pawitan $Y$, Hall $P$, Nordgren $H$, Wong JE, Liu ET, Bergh J, Kuznetsov VA, Miller LD: Genetic reclassification of histologic grade delineates new clinical subtypes of breast cancer. Cancer Res 2006, 66:10292-10301.
60. Miller LD, Smeds J, George J, Vega VB, Vergara L, Ploner A, Pawitan Y, Hall P, Klaar S, Liu ET, Bergh J: An expression signature for p53 status in human breast cancer predicts mutation status, transcriptional effects, and patient survival. Proc Natl Acad Sci USA 2005, 102:13550-13555.

61. Minn AJ, Gupta GP, Siegel PM, Bos PD, Shu W, Giri DD, Viale A, Olshen AB, Gerald WL, Massague J: Genes that mediate breast cancer metastasis to lung. Nature 2005, 436:518-524.

62. Richardson AL, Wang ZC, De Nicolo A, Lu X, Brown M, Miron A, Liao X, Iglehart JD, Livingston DM, Ganesan S: X chromosomal abnormalities in basal-like human breast cancer. Cancer Cell 2006, 9:121-132.

63. Sotiriou C, Wirapati P, Loi S, Harris A, Fox S, Smeds J, Nordgren $\mathrm{H}$, Farmer P, Praz V, Haibe-Kains B, Desmedt C, Larsimont D, Cardoso F, Peterse H, Nuyten D, Buyse M, Vijver MJ Van de, Bergh J, Piccart M, Delorenzi M: Gene expression profiling in breast cancer: understanding the molecular basis of histologic grade to improve prognosis. J Natl Cancer Inst 2006, 98:262-272.

64. Vijver MJ van de, He YD, van't Veer LJ, Dai H, Hart AA, Voskuil DW, Schreiber GJ, Peterse JL, Roberts C, Marton MJ, Parrish M, Atsma D, Witteveen A, Glas A, Delahaye L, Velde T van der, Bartelink H, Rodenhuis S, Rutgers ET, Friend SH, Bernards R: A geneexpression signature as a predictor of survival in breast cancer. N Engl J Med 2002, 347:1999-2009.

65. Wang $Y$, Klijn JG, Zhang Y, Sieuwerts AM, Look MP, Yang F, Talantov D, Timmermans M, Meijer-van Gelder ME, Yu J, Jatkoe T, Berns EM, Atkins D, Foekens JA: Gene-expression profiles to predict distant metastasis of lymph-node-negative primary breast cancer. Lancet 2005, 365:671-679. 